\title{
Coaches' Perspectives on their Roles in Facilitating the Personal Development of Student-Athletes
}

Jenessa Banwell and Gretchen Kerr

University of Toronto

\begin{abstract}
The purpose of this study was to investigate coaches' perspectives on the personal development student-athletes experience through interuniversity sport. Additionally, it explored the ways in which coaches understand, enable, and facilitate the personal development of student-athletes. Eight indepth, semi-structured interviews were conducted with male and female head coaches of Canadian Interuniversity Sport programs. A qualitative analysis of the data revealed that the coaches perceived the enhancement of studentathletes' personal development to be an important part of their role. Despite this claim, the coaches had difficulty in defining personal development and articulating how they facilitated opportunities for athletes' personal development through sport. The findings from this study have implications for future interuniversity sport programming.
\end{abstract}

\section{Résumé}

Cette étude a pour but d'examiner l'optique d'entraîneurs quant à l'épanouissement individuel de l'étudiant-athlète, au moyen d'activités sportives de niveau interuniversitaire. Par ailleurs, l'étude évaluait les moyens déployés par les entraîneurs pour comprendre, valider et faciliter cet épanouissement individuel chez l'athlète-étudiant. Pour ce faire, huit entrevues approfondies et semi-structurées ont été organisées avec les principaux entraîneurs des programmes Sport interuniversitaire canadien (SIC). C'est ainsi qu'une analyse qualitative des données a révélé que les 
entraîneurs percevaient l'amélioration de l'épanouissement individuel de l'étudiant-athlète comme un rôle important qu'ils avaient à jouer. Malgré cela, les entraîneurs définissaient difficilement ce qu'est l'épanouissement individuel et avaient du mal à articuler comment ils facilitaient la croissance individuelle de l'athlète par l'activité sportive. Les résultats de cette étude ont des répercussions sur la programmation future du sport interuniversitaire.

\section{Introduction}

University is a time to self-discover, to further one's education, and to participate in different experiences that contribute to one's educational and personal journeys. The educational mission of universities and colleges often focuses on knowledge dissemination, professional training, research expansion, and the holistic development of self (Mohanan, 2005). A common belief about university education is that the learning takes place within the classroom; however, enrolment in today's higher education institutions provides students not only with a classroom education, but also out-of-classroom experiences that contribute to their growth (Aries, McCarthy, Salovey, \& Banaji, 2004; Howard-Hamilton \& Sina, 2001; Kuh, 1993, 1995; Mixon \& Treviño, 2005; Potuto \& O’Hanlon, 2007). Significant experiences for learning and development outside the classroom include living in campus residence, having conversations with faculty and peers, working on or off campus, participating in institutional governance, being involved in clubs and organizations, and volunteering (Kuh, 1993, 1995). Another important out-of-classroom experience, and the topic of interest for this study, is interuniversity sport. It should be noted that in Canada, the term "interuniversity sport" is used to refer to varsity sport competition, while in the United States, the more common term is "intercollegiate sport."

In a national survey of Canadian universities, the key objectives of interuniversity sport were the physical, psychological, and emotional growth of student-athletes and the transmission of Canadian culture (Chelladurai \& Danylchuk, 1984). The mission statement of Canadian Interuniversity Sport (CIS), the organization with oversight of interuniversity sport, is "to enrich the educational experience of the athlete through a national sport program that fosters excellence" (CIS, 2009, p. x-i). Interuniversity sport is viewed as being consistent with the educational mission of the university because it presents students with personal and social challenges, encourages them to develop more complex views on personal, academic, and cultural matters, and provides them with opportunities for synthesizing and integrating materials presented in the formal academic program (e.g., classes, laboratories) (Kuh, 1995). Miller (2000) claimed that interuniversity sport serves as "a complement to formal classroom learning" (p. 1) and a vehicle by which student-athletes navigate important developmental tasks, including personal competence.

The role of interuniversity sport within higher education, however, is highly contested (Danish, Fazio, Nellen, \& Owens, 2002; Gould \& Carson, 2008; Hartmann \& Kwauk, 2011; Jones \& Lavallee, 2009; Petitpas, Cornelius, Van Raalte, \& Jones, 2005). On the one hand, interuniversity sport is viewed as a positive contributor to students' holistic development and learning. Researchers report that interuniversity sport increases opportunities for student-athletes to engage in the community (Mixon \& Treviño, 2005), increases retention and graduation rates (Mixon \& Treviño, 2005), and enables them to serve as role models for society in such areas as leadership, work ethic, teamwork, 
and time management (Pine, 2010). Interuniversity sport, at its best, is seen to "promote learning, personal development, and the manifestation of desirable character traits. Athletics provide for an educational experience outside of the classroom and for the physical and emotional development of participants" (Pine, 2010, p. 479).

On the other hand, research, stemming primarily from the National Collegiate Athletics Association (NCAA), reveals that student-athletes can also experience negative developmental and educational experiences through interuniversity sport participation. Noteworthy drawbacks of interuniversity sport include: hyper-commercialism and unscrupulous practices (Earl, 2004; Trani, 1995), movement away from amateurism, commercial interests and unethical behaviours (Trani, 1995), unjustified financial investments in athletic programs (Pine, 2010), and exploitation of athletes (Pierce, 2010). An abundance of literature has also focused on the social isolation and segregation of athletes from their non-athlete peers (Bowen \& Levin, 2003; Shulman \& Bowen, 2001; Umbach, Palmer, Kuh, \& Hannah, 2006), as well as negative academic outcomes associated with student-athletes' participation in interuniversity athletics (McBride \& Reed, 1998; Pascarella et al., 1999). Although these concerns have received some attention in Canadian university sport, they are largely characteristic of the American university sport context.

The role of interuniversity sport within higher education-and, more specifically, the contributions it makes to student-athlete learning and personal development-is therefore inconclusive. It is also important to note that the majority of the existing research on interuniversity sport has been conducted in the United States (Aries et al., 2004; Earl, 2004; Eitzen, 1987; Gayles, 2009; Howard-Hamilton \& Sina, 2001; Mixon \& Treviño, 2005; Pierce, 2010; Pine, 2010; Potuto \& O’Hanlon, 2007; Trani, 1995; Umbach et al., 2006; Williams \& Pennington, 2006), which has a very different culture of university sport compared to Canada. Canadian interuniversity sport continues to emphasize a "student first, athlete second" approach, whereas, Division 1 university sport in the United States has been referred to as a "big business" with high operating budgets and increased emphasis on revenue production (Danylchuk \& MacLean, 2001). We therefore argue that US data cannot be generalized to the Canadian interuniversity sport context.

Furthermore, the existing literature focuses on student-athletes' perceptions of sportrelated outcomes and has not addressed the role that coaches may play in athletes' development. Instead, current research addressing the role of the university coach focuses on: the relationship between organizational support, work-family conflict, and job-life satisfaction amongst university coaches (Dixon \& Sagas, 2007); how expert university coaches of team sports build their successful programs (Vallée \& Bloom, 2005); and the development and acquisition of coaching knowledge by university coaches who have surpassed their personal athletic achievements (Carter \& Bloom, 2009). The purpose of this study therefore was to explore coaches' perceived roles in facilitating the personal development of student-athletes through Canadian interuniversity sport participation. For the purpose of the current study, personal development is defined as encompassing a range of developmental tasks that contribute to whole person development, including psychological, emotional, social, cognitive, moral, and personal growth. The ultimate goal of personal development is to achieve status as a contributing, fully functioning member of society (adapted from Gould, Chung, Smith, \& White, 2006; Miller, 2000; Trudel, 2006; Weiss \& Wiese-Bjornstal, 2009). 


\section{Methods}

\section{Participants}

Eight head coaches of Canadian interuniversity athletic teams were recruited to participate in this study. These interuniversity coaches-both male $(\mathrm{n}=4)$ and female $(\mathrm{n}=$ 4)-represented full-time $(n=5)$ and part-time $(n=3)$ coaching positions and encompassed both team $(\mathrm{n}=6)$ and individual sports $(\mathrm{n}=2)$, including women's teams $(\mathrm{n}=$ $4)$, men's teams $(n=2)$, and mixed-athlete teams $(n=2)$. In addition, seven of the eight participants were former university student-athletes.

To ensure a diverse sample, coaches were selected from a variety of CIS sports. The sample in this study represented basketball, field hockey, hockey, swimming, track and field, and volleyball. No more than three coaches from the same interuniversity sport and no more than four coaches from the same university were included in the sample. The length of the participants' coaching careers ranged from two to 33 years.

\section{Measures}

Previous studies examining the roles of either coaches or student-athletes in the interuniversity sport context have employed quantitative approaches (Aries et al., 2004; Mixon \& Treviño, 2005; Potuto \& O'Hanlon, 2007; Umbach et al., 2006). This study employed a qualitative approach to provide a complex, detailed understanding of student-athletes' personal development through interuniversity sport (Côté, 1993). In-depth semi-structured interviews were used to learn about the participants' perspectives and to advance the literature, given that previous research has relied on quantitative approaches. Côté (1993) argued that the "in-depth interview is one of the most valuable techniques for truly understanding the richness of another person's perspective” (p. 52).

\section{Procedures}

We used a purposive method of sampling, which involved selecting research participants based on their knowledge and understanding of the phenomena under study (Streubert Speziale \& Carpenter, 2007). Coaches were purposively sampled to provide a range of tenure, as coaches' experience may influence their perspectives on their roles in facilitating personal development. Purposive sampling has been used in previous qualitative research involving the recruitment of coaches (Headley-Cooper, 2010; Poczwardowski, Barott, \& Henschen, 2002). Once approval for the study was received from the human ethics board, coaches were recruited via emails asking about their potential interest in participating.

Interviews were conducted by phone $(\mathrm{n}=5)$ and in person $(\mathrm{n}=3)$ and lasted between 30 and 80 minutes. An information letter and informed consent form were emailed to each participant; the consent forms were returned to the first author in hard copy for all participants who were interviewed in person and via fax and/or scan for those participants interviewed over the phone. With each participant's consent, interviews were audio-recorded. Each interview began with general questions about the participant's coaching history, such as, "How long have you been coaching in the sport?" Following this, more specific questions related to the purpose of the study were posed, such as, "What do you hope your athletes will take away as a result of their interuniversity sport experience? Other than sportspecific skills, what personal or transferable life skills do you hope your athletes will learn 
and develop as a result of their sport participation? What experiences and/or opportunities do you feel are provided by interuniversity sport for student-athletes' personal development? Do coaches have a role to play in enabling these opportunities for personal growth? In what ways do coaches facilitate the personal growth of their athletes?"

\section{Data Analysis}

After completing each individual interview, the digital recordings were transcribed verbatim by the first author. Any identifiable information pertaining to the participant was eliminated from the transcribed text (e.g., name of coach, names of student-athletes). Each participant has also been assigned a pseudonym.

An inductive approach "includes the voices of the participants, the reflexivity of the researcher, and a complex description and interpretation of the problem, and it extends the literature" (Creswell, 2007, p. 37). The inductive approach in this study followed a "bottom-up" method whereby meaning units were created and then further translated into categories, and finally those categories were analyzed into higher-order themes (Côté, Salmela, \& Russell, 1995).

\section{Findings}

The data are categorized into two themes: the first includes coaches' conceptualizations of personal development, and the second explores coaches' reported influence on athletes' personal development. The organization of the higher- and lower-order themes is presented in Table 1.

Table 1.

Organization of Higher-order and Lower-order Themes

\begin{tabular}{lll}
\hline Higher-order Themes & Lower-order Themes & Raw Data Examples \\
\hline $\begin{array}{l}\text { Conceptualizations of } \\
\text { Personal Development }\end{array}$ & $\begin{array}{l}\text { Prioritizing student-athletes' } \\
\text { personal development }\end{array}$ & $\begin{array}{l}\text { Student first, athlete second } \\
\text { Implicit component of sport }\end{array}$ \\
& Athletes' academic success & GPA, university degree \\
& Self-acceptance & Accepting who you are \\
& Learning life skills & $\begin{array}{l}\text { Time management, work ethic, ac- } \\
\text { countability, leadership }\end{array}$ \\
$\begin{array}{l}\text { Influence of Coaches } \\
\text { on Athletes' Personal } \\
\text { Development }\end{array}$ & Modeling and mentoring & $\begin{array}{l}\text { Leading by example } \\
\text { Building relationships }\end{array}$ \\
& $\begin{array}{l}\text { Building trust and being honest with } \\
\text { athletes }\end{array}$ \\
& Reflection & $\begin{array}{l}\text { Personal reflection and one-on-one } \\
\text { meetings with athletes }\end{array}$ \\
\hline
\end{tabular}




\section{Conceptualizations of Personal Development}

Prioritizing student-athletes' personal development. All eight participants claimed that athletes experienced personal development as a result of their interuniversity sport participation. Michael explained that it is up to the coach to put together a framework around personal development, and that doing so places importance on personal development in the eyes of his female athletes. He also said:

Well, I think coaches do, I don't want to say all of it [laughs], but coaches put the framework together in order for [personal development] to be able to happen. If it's not important to the coach, then I don't think it's necessarily going to happen just by accident. It might, but I don't think it's likely.

Participants emphasized a "student first, athlete second" approach and the importance of defining what student-athlete success really means, so that the athletes have a clear understanding. Sandra stated, "One thing I say to all of the athletes is, 'You're here to go to school, you're not here to [play sport].' School comes first." Cindy added that success is not defined by a championship at the end of a season but by how student-athletes have learned and grown throughout their participation in university sport. Alice believed the personal development of athletes should be an implicit component of interuniversity sport:

It's important that we care about the athletes. ... I always felt comfort in knowing that the educational component of the [interuniversity] sport experience was an important piece and that [athletic] success was kind of a by-product of the educational component. I mean I'm competitive and I want to win and all that kind of stuff ... but we also want to [personally] develop these athletes.

Coaches defined student-athletes' personal development as academic success, selfacceptance, and the learning of life skills. Each characteristic will now be discussed.

Athletes' academic success. Most coaches viewed grade point average (GPA), the attainment of a degree, and the overall academic success of their athletes as indicators of the athletes' personal development.

When Cindy discussed how she assessed the personal development of her female athletes, she declared, "I ask how they're doing academically. ... I write down notes on how they're doing academically. ... [I]f we see them doing better in school, that's a good [sign]." Other coaches shared similar viewpoints; Paul said, "We certainly discuss [personal development] as a coaching staff ... and it's through the academic meetings we have and the one-on-one meetings [that] we discuss those things and try and point them in the right directions."

The policy of the athletic department at Steven's university stipulated that a team GPA and a team's ability to graduate student-athletes were linked to athletes' personal development. When discussing the conversations his department head had had about studentathlete personal development, Steven explained:

I am responsible for the overall team's GPA. So what [the athletic department] wants to see is graduating athletes. ... [T] he new Athletic Director hired me; I am responsible to recruit [and] make sure the [team] GPA gets to at least a B average and we're graduating athletes. 
Steven then went on to say:

[My university] has done an unbelievable job of spending money in good areas and creating an infrastructure. One area is the academic area.... [E]very varsity athlete gets free tutoring. ... [W] now have a full-time professor; he has seven mentors and 22 tutors under him.

Earning a degree was perceived as an indicator of personal development. Paul thought, first and foremost, that his student-athletes were at university to earn a degree and that the journey to the degree exemplified personal development. Paul shared a story of one of his former male student-athletes to illustrate:

We had an athlete who definitely had a tougher time ... and this definitely translated in the classroom as well. He definitely struggled in his first few years.... [H]e sort of locked horns with whomever he dealt with and in his third year, he took five classes in each semester and succeeded basically because his back was up against a wall. Being there on graduation day with his parents was something that was very special, you know. His mother said that she never thought that this day would be possible.... [S]o the evolution of the person we saw ... now he's got a degree.

Steven said, "I want them to be hirable," and believed that an indicator of a successful program, in terms of its commitment to supporting athletes' personal development, is whether or not those athletes are being hired post-graduation. Steven stated, "[University A] and [University B] have done an incredible job in enhancing the athlete. I can say that by the success of the program, the marks those kids are getting, and [because] those kids are getting hired."

The emphasis coaches placed on academics was evident through such comments as: "We put academics first ... we do our best to help them succeed in school" (Cindy); "first and foremost the reason [student-athletes] are here is for a degree" (Paul); and "you're not here to [play sports]. School comes first" (Sandra). Michael completed the point by stating, "If [academic achievement is] not important to the coach, then I don't think it's necessarily going to happen just by accident."

Self-acceptance. This term was referenced by some of the coaches throughout the interviews, regarding characteristics that best define athletes' personal development. Throughout Mary's coaching career of more than 15 years with her co-ed university team, she had witnessed athletes' individual battles with realizing and accepting who they were as they navigated these conflicts. For example:

We had a boy come out almost two years ago now ... and he was one of the captains on our team, too, so it was wonderful. . . . I said, "When did you know?" because I find it fascinating, and he said, "About when I was 11 years old I knew I wasn't normal," and he was sitting right there and I banged on the desk and I said, "Never let me hear you say you're not normal again!" and he burst into tears and said, "Thank you so much." 
Mary went on to say:

There were a couple of guys who were a bit homophobic, but when [an athlete] came out it was kind of like, "Hey, it's ok." Like, "So you're gay! You're gay! That's just one facet of you, like I don't care. Like get on the [court and play]. Shut up and [play]. Who cares, it's just one part of you." So, to get them to learn self-acceptance.

Likewise, Alice recognized the importance of accepting who one is and explained:

I hope that they can have a clear sense of who they are, be able to stick up for themselves in any setting, whether it be a relationship setting or a job.... That they can confront any challenges, in any aspect, that they have tremendous strength and courage.

Michael tied together the points made by Mary and Alice when he said, "It's really about just the process of being true and honest with yourself, and it's a skill that [coaches] want you to have when you leave. It can be hard, but I think athletics can really do that.”

Learning life skills. During the interviews, almost all of the coaches frequently referred to "life skills." Participants identified several transferable life skills that they hoped their athletes would take away from their experience in university sport; in some cases, coaches felt these skills could only be afforded to those people who participate in sport. According to Michael, "The ability to have a conversation, to have a difficult conversation, is something [that] if you don't play sports, it's possible to avoid completely." Steven agreed:

I think the ability to speak. You can be the greatest student you want, but you still have to go to the job interview and be able to communicate your ideas clearly and concisely and you have to have social skills ... and I really believe that my [athletes] will develop social skills.

A life skill that the coaches frequently identified was time management. Both Alice and Mary recognized the multiple commitments their athletes had and believed balancing these was essential. Alice explained:

The students here are fascinating. It's amazing that they can manage the time that they have.... [T] hey fill in their academics, and their study time, and their eating time, and their everything time and then they look at it and say, "Wow!" There's no time in there!

Mary added to this by sharing:

Because [our sport] is extremely time consuming, [the athletes] are forced to organize themselves and at the beginning of the year we give them a template and say, "Mark in all of your classes, and mark off which workouts you plan to attend." And that might change, but they commit to that and they know that three times a week we have [workouts].

Coaches believed their players learned work ethic (Sandra), accountability (Paul), leadership (Sam), and teamwork (Cindy) through sport. Sam spoke to the learning of leadership when he shared: 
Decisions have to be unanimous. I allow the captains to make the decisions; our rule is if it gets to me then that's it. That's the final say. That's the rule and that's the way it's going to be. So you have to come up with something so that everyone's happy, and it teaches [the captains] to compromise and to lead, and it teaches [the captains] to make decisions that are good for the team, not just good for you and your friends. That's an example of where leadership would come in.

Sam also discussed how learning to operate within a team is fostered through sport.

[Learning] to deal with all kinds of people ... the good athletes, the bad athletes, the good coaching and the bad coaching.... [H] ow are you going to deal with that? How are you going to work in a team concept? Those are things that I really feel that you'll get first-hand experience through sport.

The following section will address coaches' perceptions about their role in advancing athletes' personal development.

\section{Influence of Coaches on Athletes' Personal Development}

Absent from all of the coaches' responses were any experiences facilitated and implemented by them to enable and support the personal development of student-athletes. Only once the researcher asked whether the participants believed they, as coaches, played a role in facilitating their athletes' personal development did they begin to discuss their influence. Once participants were prompted to talk about their role in supporting and facilitating athletes' personal development, three themes arose: modeling and mentoring, building relationships with athletes, and reflection.

Modeling and mentoring. When prompted about their role in facilitating opportunities for personal development, most of the coaches provided several illustrations of how they model the way for their athletes,-for instance: "I think leading by example" (Sandra), "and be a mentor to them" (Steven), "I still think of coaches as mentors, I still think that's the biggest thing" (Michael). Michael provided a specific example:

[Our school] speaks to elementary schools about success. ... I really wanted her [an athlete] to go [speak]. ... I thought it would be good for her to go and get out of her comfort zone and speak to 150 kids and present her thoughts to those kids.

Michael stated that although mentorship could come from other athletes on the team, the mentorship that comes from coaches has a larger impact. "I just think where [athletes] learn to place importance on things is where their coaches place importance on things."

Similarly, Steven believed coaches could influence their athletes' personal development through mentorship:

The biggest problem I deal with is getting [athletes] to think by themselves. In [youth sport], they are told when to get up, where to be, what to do, what time to get on the bus, and what time the lights are out. My biggest job [as head coach] is to get [athletes] to do that on their own and to make good decisions. I think that's pretty important. ... I'm not going to tell you when to study, but you have to study ... and that's where I think I can coach them a little bit and be a mentor to them. Give them the tools to support that. 
In addition to mentoring athletes, participants frequently cited leading by example. Sandra provided an illustration:

Well, I think leading by example. I know that some coaches [play] their athletes when they're injured [or] train their athletes when they are injured, and I don't think that teaches them anything. Also, if you're inflexible, that teaches them to be inflexible-my way or the highway kind of thing. So I think it's leading by example.

Sandra expanded on her point, stating that sometimes coaches can set negative examples, which may inhibit athletes' personal development.

A lot of times there are coaches who allow negative atmospheres to carry on.... Those [athletes] will learn something [after they have left] about that environment and reflect back on it, but when they are in that environment, I'm not necessarily certain that they are growing in a positive manner if that's the culture that the [coach] is encouraging. So, yes, I think it's mostly lead by positive example.

Alice also asserted that coaches could influence the personal development of their athletes in both positive and negative ways:

I think [coaches] can influence in good and bad directions.... [F]or sure they have an opportunity to influence if they want to ... how they teach the athletes to train, to work, to cope in stressful situations and not just to cope, but to lead through a stressful situation. So how [coaches] cope is something that [athletes] will take forward, and whether [coaches] know it or not, they could be providing great examples or horrible examples.

Alice suggested that coaches should be acutely aware of the behaviours they model because, whether intentionally or not, athletes learn from the actions and examples of their coaches.

Participants suggested that in addition to modeling and mentoring, they influenced athletes' personal development through building relationships and reflection.

Building relationships. A few coaches mentioned their ability to build relationships with their athletes as a vehicle of influence for athletes' personal development. Participants noted: "[b]uilding relationships [with athletes]" (Alice); "you overcome [barriers to personal development] by building relationships [with athletes]" (Sam); "[my athletes] know I am there and I have dealt with everything [of concern to them]" (Mary).

Alice explained, "It's all about building relationships. You have to build relationships with the staff, the staff have to build relationships with the athletes ... so it's about building trust ... finding ways to build relationships and build trust within [those relationships]." Alice believed her full-time head coach position helped her build trust with her male and female athletes:

I think an investment in full-time leadership is important because I think that with full-time leadership you can have someone who pays attention to more than just the x's and o's [of the athletes]... . So it has to be both pieces ... I think full-time leadership and a [coach] who works really hard to build relationships [with athletes]. 
Sam discussed the importance that he places on being honest with his female athletes as a way to facilitate their personal development.

As a coach this is where that question of inhibition comes in; if you lie to [an athlete] and you don't tell them where they stand then you are in fact inhibiting them because you are telling them something that is not true. So that is what I have learned ... tell them the way it is and let them make the decision.... So as a coach you have the responsibility to tell the [athletes] why you are making the decisions you're making. Now, not all coaches will agree with that philosophy, they don't feel like they owe that to the athletes. I do. That's my philosophy. For me, it helps with [athletes'] personal growth.

Similarly, Cindy stressed the value of being honest with her female athletes:

I've got players who haven't played in games, but they've been on the bench and stuff and I talk to them more often [than athletes who play] and say, "You're making our team better, in practice you're making our team better by how supportive and positive you are on the bench." I think it's so important to be honest with [athletes].... I let them know at the beginning of the season, "I don't see you playing much this season, you can practice with us and play in exhibition games, but I don't so much see you playing."

Reflection. A small number of coaches also cited reflection as a medium through which they could influence athletes' personal development. Michael and Sam mentioned spending a lot of time in reflection, both with and without their athletes. Michael discussed a program that gives his female athletes the opportunity to speak to elementary school youth about success; he explained that taking the time to sit down one-on-one in his office following their visit to the elementary school facilitated reflection and learning from the experience. The time spent in reflection with his athletes, to Michael, is the most valuable piece:

To know [as a coach] what area [athletes] need to grow in, then to put them in that situation. Afterwards, for [the athlete] to come in and talk about it and reflect on it. Well, how did it go? How was this part of it? What did you think of this? The reflection part of it and debrief of [the experience], I think that's where they learn.

Sam believed it was important for coaches to individually reflect on athletes' experiences of personal development: "I spend a lot of time with reflection; I think if you don't reflect, it's hard for [coaches] to get better." According to Sam, when his athletes submit midterm reports on the season, he reviews these reports and uses this time for reflecting on how he can strengthen his relationships with his female athletes and, in turn, enhance their personal development.

\section{Limitations}

We acknowledge limitations associated with this study. At the outset, this study explored the lone perspective of coaches on the phenomenon of interest. Athletes' perspectives on personal development were not included in this study because of the over-repre- 
sentation of athletes' views in the existing literature (Gayles, 2009; Miller, 200o; Potuto \& O'Hanlon, 2007) and coaches' consequent under-representation. This study was also limited to CIS head coaches, excluding assistant coaches. As head coaches are often responsible for the design and implementation of their university sport programs, it was hypothesized that head coaches would be better able than assistant coaches to speak to areas relating to athletes' personal development. However, it is possible that the personal development of athletes in university sport programs is also a responsibility of assistant coaches, and the limiting criteria of this study neglected to include their perspectives. In addition, email was chosen to recruit CIS head coaches because it was time- and cost-effective. It is possible that only individuals who had positive perceptions of personal development chose to respond, thus creating a bias in our sample. The exclusive use of interviews for data collection may have limited the findings, as no additional methods were employed to assess the validity of coaches' interview statements. In future research, attempts should be made to include secondary methods of data collection, such as researcher observation and/or interviews with athletes.

\section{Discussion}

Findings from the current study revealed that the coaches had difficulty articulating the concept of personal development and ways in which they help support and facilitate athletes' personal development through sport. Instead of describing personal development, they instead referred to life skills development and academic performance. It is possible that the coaches in this study assessed athletes' personal development based on GPAs or success in the classroom because these are observable and measurable. Previous studies examining personal development have used academic progress and/or classroom success as a measure, but these lack legitimacy in their correlation with personal development (Barna \& Brott, 2011; Gilbert \& Trudel, 2000; Hughes \& Marsh, 2000). Furthermore, the correlation between personal development and GPA does not address the impact of sport or the coach's influence on athletes' personal development through sport. It is not surprising that the coaches over-emphasized life skills as representative of personal development, given that the vast majority of research to date conducted on development through sport focuses on athletes' development of life skills (Camiré, 2012; Gould et al., 2006; Gould \& Carson, 2008; Gould, Collins, Lauer, \& Chung, 2007; Hanson, Larson, \& Dworkin, 2003; Holt, Tink, Mandigo, \& Fox, 2008; Pierce, 2010; Potuto \& O’Hanlon, 2007). Life skills are defined as "those internal personal assets, characteristics, and skills such as self-esteem and hard work ethic that can be facilitated or developed in sport and are transferred for use in non-sport settings" (Gould \& Carson, 2008, p. 60). Coaches discussed several examples of life skills, including leadership, self-confidence, time management, conflict resolution, and accountability. Personal development, however, is not synonymous with life-skills development and/or academic development (Gould et al., 2006; Roth \& Brooks-Gunn, 2003). Rather, it is the outcome of multiple learning opportunities that, together, construct the development of the individual (Lerner, 2004; Roth \& Brooks-Gunn, 2003). Lack of research and dialogue within sport communities about athletes' personal development through sport may be contributors to coaches' inability to conceptualize personal development. 
Coaches also exhibited difficulty articulating their role in facilitating and enabling personal development inside of the sport arena. While they referred to such avenues as modeling, building relationships, and reflection, these may be interpreted as rather indirect influences, none of which refer specifically to behaviours coaches may use to enhance the personal development of athletes. For example, one might have expected to hear about the intentional development of leadership by assigning athletes to organize and lead team warm-ups; ideally this would be followed by the coaches providing feedback and drawing explicit linkages between these roles and similar ones in non-sport settings, such as school or the workplace.

Coaches' difficulties in articulating the ways in which they facilitated the personal development of student-athletes may be interpreted through the concepts of declarative and procedural knowledge (Elferink-Gemser, Kannekens, Lyons, Tromp, \& Visscher, 2010; Giacomini, Soares, Santos, Matias, \& Greco, 2011; Williams \& Davids, 1995). Declarative knowledge refers to factual information that we are consciously aware of and can clearly express (Baumard, 1999; Williams \& Davids, 1995). Procedural knowledge is knowing how to do something and the ways to do things (Sahdra \& Thagard, 2003). The coaches in the current study exemplified strong declarative knowledge with respect to life-skills development but inadequate declarative knowledge in reference to personal development.

The coaches also demonstrated difficulty articulating how they helped support athletes' personal development through sport, thus suggesting weak procedural knowledge. When participants were asked how they helped facilitate and support athletes' personal development, none of the participants described how they enabled opportunities for personal development using sport as the medium. For example, coaches explained mentoring their athletes, being truthful, building trusting relationships, and the importance of defining student-athlete success as personal and performance excellence. None of their examples indicated the use of sport as the vehicle for learning. This suggests that coaches must consciously work to facilitate opportunities for personal development through sport instead of assuming they will occur naturally.

Giacomini and colleagues (2011) proposed that declarative knowledge precedes procedural knowledge, a theory that was reinforced by this study. The current findings reveal that coaches' lack of knowledge of what personal development is inevitably hinders their ability to articulate ways of facilitating personal development through sport. For coaches to better articulate and make explicit the influence(s) they have in the facilitation of athletes' personal development within the arena of sport (doing), they must first learn what personal development is (knowing).

There were no clear differences in coaches' perspectives on their role in facilitating athletes' personal development based on tenure. However, it is proposed that the coaches' own interuniversity sport experiences as student-athletes negatively correlated with their abilities to articulate what is meant by personal development, as well as with their ability to articulate methods of facilitating personal development through sport. Seven of the eight coaches had been competitive athletes at the interuniversity level. The coaches talked about how much they had learned from sport and the life lessons they had taken away from the university student-athlete experience, including learning how to deal with people from different walks of life, having respect for others, self-responsibility, how to room/live with someone, how to travel, how to prepare oneself, how to win and lose, and 
how to rebound from getting cut. Coaches claimed that sport participation had benefitted their careers, relationships, education, and overall quality of life, which is consistent with existing literature on the transferability of life skills learned through sport to other areas outside of the sport context (Barton, 2012; Gould \& Carson, 2008; Jones \& Lavallee, 2009). Despite these findings, coaches lacked the ability to confidently articulate the ways in which they helped to support the personal development of their athletes. This finding has similarities with the study conducted by McCallister, Blinde, and Weiss (2000), who indicated that coaches might be socialized to believe sport facilitates positive developmental outcomes, but they may not be implementing strategies that accomplish these outcomes. Coakley (2011) and others (Danish et al., 2002; Gould \& Carson, 2008; Hartmann \& Kwauk, 2011; Jones \& Lavallee, 2009; Petitpas et al., 2005) have argued that sport in and of itself is insufficient to facilitate positive developmental outcomes. Only with coaches' purposeful implementation of specific conditions conducive to development are positive developmental outcomes made possible through sport participation. It could be argued, therefore, that without developed declarative and procedural knowledge, coaches are inhibited in their abilities to facilitate the personal development of student-athletes through sport.

To help coaches make athletes' personal development through sport more purposeful, interuniversity sport programming should include a framework, specific to athletes' personal development, that coaches can use and incorporate into their sport programs. It would be beneficial for professionals with training in student development to assist in the design and direction of these programs in athletics (Carter \& Bloom, 2009; Libby, 2007) and, more importantly, work in conjunction with coaches to deliver them. Having a purposeful and strategic framework may make the facilitation of athletes' personal development more explicit rather than assuming it is an automatic by-product of sport participation. This would help coaches better understand what personal development is and how they, as coaches, can help to facilitate personal development through sport.

\section{References}

Aries, E., McCarthy, D., Salovey, P., \& Banaji, M. R. (2004). A comparison of athletes and nonathletes at highly selective colleges: Academic performance and personal development. Research in Higher Education, 45(6), 577-602.

Barna, J. S., \& Brott, P. E. (2011). How important is personal/social development to academic achievement? The elementary school counselor's perspective. Professional School Counseling, 14(3), 242-249.

Barton, G. B. (2012). Career success and life skill development through sports. Retrieved from ProQuest Dissertations and Theses. (3463117)

Baumard, P.(1999). Tacit knowledge in organizations. London, UK: Sage Publications.

Bowen, W. G., \& Levin, S. A. (2003). Reclaiming the game: College sports and educational values. Princeton, NJ: Princeton University Press.

Camiré, M. (2012). Facilitating positive youth development through high school sport (Doctoral dissertation). Retrieved from https://www.ruor.uottawa.ca/ handle/10393/22903 
Canadian Interuniversity Sport (CIS). (2009). Canadian Interuniversity Sport bylaws, policies, and procedures. Retrieved from http://english.cis-sic.ca/information/ members_info/pdfs/pdf_bylaws_policies_procedures/1_2009-10_Policies_title_ page_Index_Vision_10_Pt_Plan.pdf?dec=

Carter, A. D., \& Bloom, G. A. (2009). Coaching knowledge and success: Going beyond athletic experiences. Journal of Sport Behavior, 32(4), 419-437.

Chelladurai, P., \& Danylchuk, K. E. (1984). Operative goals of intercollegiate athletics: Perceptions of athletic administrators. Canadian Journal of Applied Sport Sciences, 9(1), 33-41.

Coakley, J. (2011). Youth sports: What counts as “positive development?” Journal of Sport and Social Issues, 35(3), 306-324.

Côté, J. (1993). Identification and conceptualization of expert high performance gymnastic coaches' knowledge. Retrieved from https://www.ruor.uottawa.ca/ handle/10393/6810

Côté, J., Salmela, J. H, \& Russell, S. (1995). The knowledge of high performance gymnastics coaches: Competition and training considerations. The Sport Psychologist, 9(1), 76-95.

Creswell, J. W. (2007). Qualitative inquiry and research design: Choosing among five traditions (2nd ed.). Thousand Oaks, CA: Sage Publications.

Danish, S. J., Fazio, R. J., Nellen, V. C., \& Owens, S. S. (2002). Teaching life skills through sport: Community-based programs to enhance adolescent development. Washington, DC: American Psychological Association.

Danylchuk, K. E., \& MacLean, J. (2001). Intercollegiate athletics in Canadian universities: Perspectives on the future. Journal of Sport Management, 15(4), 364-379.

Dixon, M. A., \& Sagas, M. (2007). The relationship between organizational support, work-family conflict, and the job-life satisfaction of university coaches. Research Quarterly for Exercise and Sport, 78(3), 236-247.

Earl, J. W. (2004). The faculty's role in reforming college sports. Academe, 9o(5), $53-57$.

Eitzen, D. S. (1987). The educational experiences of intercollegiate student athletes. Journal of Sport and Social Issues, 11, 15-30.

Elferink-Gemser, M. T., Kannekens, R., Lyons, J., Tromp, Y., \& Visscher, C. (2010). Knowing what to do and doing it: Differences in self-assessed tactical skills of regional, sub-elite, and elite youth field hockey players. Journal of Sport Sciences, 28(5), 521-528.

Gayles, J. G. (2009). The student athlete experience. New Directions for Institutional Research, 144, 33-41. doi:10.1002/ir.311

Giacomini, D. S., Soares, V. O., Santos, H. F., Matias, C. J., \& Greco, P. J. (2011). Procedural and declarative tactical knowledge in soccer players of different ages. Motricidade, 7(1), 43-53. 
Gilbert, W. D., \& Trudel, P. (2000). Validation of the Coaching Model (CM) in a team sport context. International Sports Journal, 4(2), 120-128.

Gould, D., \& Carson, S. (2008). Life skills development through sport: Current status and future directions. International Review of Sport and Exercise Psychology, 1(1), 58-78.

Gould, D., Chung, Y., Smith, P., \& White, J. (2006). Future directions in coaching life skills: Understanding high school coaches' views and needs. Athletic Insights: The Online Journal of Sport Psychology, 18(3), 28-38.

Gould, D., Collins, K., Lauer, L., \& Chung, Y. (2007). Coaching life skills through football: A study of award winning high school coaches. Journal of Applied Sport Psychology, 19(1), 16-37.

Hansen, D. M., Larson, R. W., \& Dworkin, J. B. (2003). What adolescents learn in organized youth activities: A survey of self-reported developmental experiences. Journal of Research on Adolescence, 13(1), 25-55.

Hartmann, D., \& Kwauk, C. (2011). Sport and development: An overview, critique, and reconstruction. Journal of Sport and Social Issues, 35(3), 284-305. doi:10.1177/0193723511416986

Headley-Cooper, K. J. (2010). Coaches' perspectives on athlete-centred coaching (Unpublished master's thesis). University of Toronto, Toronto, ON. Retrieved from https://tspace.library.utoronto.ca/bitstream/1807/24252/1/Headley-Cooper_ Karlene_J_201003_MSc_thesis.pdf

Holt, N. L., \& Neely, K. C. (2011). Positive youth development through sport: A review. Revista de Iberoamericana de Psicología eel Ejercicio y el Deporte, 6(2), 299-316. Retrieved from dialnet.unirioja.es/descarga/articulo/3857557.pdf

Holt, N. L., Tink, L. N., Mandigo, J. L., \& Fox, K. R. (2008). Do youth learn life skills through their involvement in high school sport? A case study. Canadian Journal of Education, 31(2), 281-304.

Howard-Hamilton, M. F., \& Sina, J. A. (2001). How college affects student athletes. New Directions for Student Services, (93), 35-45.

Hughes, L. D., \& Marsh, B. A. (2000). Achieving personal and academic success. [Review of the book Achieving personal and academic success, by T. Petrie]. Journal of College Student Development, 41(3), 366-367.

Jones, M., \& Lavallee, D. (2009). Exploring the life skills needs of British adolescent athletes. Psychology of Sport and Exercise, 10(1), 159-167.

Kuh, G. D. (1993). In their own words: What students learn outside the classroom. American Educational Research Journal, 30(2), 277-304.

Kuh, G. D. (1995). The other curriculum: Out-of-class experiences associated with student learning and personal development. The Journal of Higher Education, 66(2), 123-155.

Lerner, R. M. (2004). Liberty: Thriving and civic engagement among America's youth. Thousand Oaks, CA: Sage Publications. 
Libby, S. (2007). Faculty members discuss what role they should play in athletics. The Chronicle of Higher Education, 54(9), 12.

McBride, R. E., \& Reed, J. (1998). Thinking and college athletes: Are they predisposed to critical thinking? College Student Journal, 32, 443-450.

McCallister, S. G., Blinde, E. M., \& Weiss, W. M. (2000). Teaching values and implementing philosophies: Dilemmas of the coach. Physical Educator, 57, 35-45.

Miller, P. S. (2000). Student-athletes' perceptions of psychosocial development through intercollegiate athletic participation (Unpublished doctoral dissertation). University of Toronto, Toronto, ON. Retrieved from http://hdl.handle.net/1807/14190

Mixon, F. G., \& Treviño, L. J. (2005). From kickoff to commencement: The positive role of intercollegiate athletics in higher education. Economics of Education Review, 24, 97-102.

Mohanan, K. P. (2005). University education for career advancement: The profile of a successful candidate. Singapore: Centre for Development of Teaching and Learning, National University of Singapore. Retrieved from http://www.cdtl.nus.edu.sg/ publications/career/

Pascarella, E. T., Truckenmiller, R., Nora, A., Terenzini, P. T., Edison, M., \& Hagedorn, L. S. (1999). Cognitive impacts of intercollegiate athletic participation: Some further evidence. Journal of Higher Education, 70, 1-26.

Petitpas, A., Cornelius, A., Van Raalte, J., \& Jones, T. (2005). A framework for planning youth sport programs that foster psychosocial development. Sport Psychologist, 19(1), 63-80.

Pierce, S. W. (2010). The role of intercollegiate sport participation in life skills development: Collegiate athletes' perspectives (Unpublished master's thesis). Miami University, Miami, FL. Retrieved from http://rave.ohiolink.edu/etdc/view?acc_ num $=$ miami1281116999

Pine, N. (2010). The role of athletics in the academy: An alternative approach to financial investment. Journal of Sport and Social Issues, 34(4), 475-480.

Poczwardowski, A., Barott, J. E., \& Henschen, K. P. (2002). The athlete and coach: Their relationship and its meaning. Results of an interpretive study. International Journal of Sport Psychology, 33, 116-140.

Potuto, J. R., \& O'Hanlon, J. (2007). National study of student-athletes regarding their experiences as college students. College Student Journal, 41(4), 947-966.

Roth, J. L., \& Brooks-Gunn, J. (2003). What exactly is a youth development program? Answers from research and practice. Applied Developmental Science, 7, 94-111.

Sahdra, B., \& Thagard, P. (2003). Procedural knowledge in molecular biology. Philosophical Biology, 16(4), 477-498.

Shulman, J. L., \& Bowen, W. G. (2001). The game of life. Princeton, NJ: Princeton University Press.

Streubert Speziale, H. J., \& Carpenter, D. R. (2007). Qualitative research in nursing: Advancing the humanistic imperative (4th ed.). Philadelphia, PA: Lippincott Williams \& Wilkins. 
Trani, E. P. (1995, March 17). The distorted landscape of intercollegiate sports. The Chronicle of Higher Education, pp. B1-B2.

Trudel, P. (2006). What the coaching science literature has to say about the roles of coaches in the development of elite athlete. International Journal of Sports Science \& Coaching, 1(2), 127-130.

Umbach, P. D., Palmer, M. M., Kuh, G. D., \& Hannah, S. J. (2006). Intercollegiate athletes and effective educational practices: Winning combination or losing effort? Research in Higher Education, 47(6), 709-733.

Vallée, C. N., \& Bloom, G. A. (2005). Building a successful university program: Key and common elements of expert coaches. Journal of Applied Sport Psychology, 17(3), 179-196.

Weiss, M. R., \& Wiese-Bjornstal, D. M. (2009). Promoting positive youth development through physical activity. President's Council on Physical Fitness and Sports Research Digest, $10(3), 1-8$.

Williams, M., \& Davids, K. (1995). Declarative knowledge in sport: A by-product of experience or a characteristic of expertise? Journal of Sport and Exercise Psychology, 17, 259-275.

Williams, M. R., \& Pennington, K. (2006). Community college presidents' perceptions of intercollegiate athletics. The Community College Enterprise, 12(2), 91-104.

\section{Contact Information}

Jenessa Banwell

Faculty of Kinesiology and Physical Education

University of Toronto

jenessa.banwell@utoronto.ca

Jenessa Banwell is currently a PhD student in the Department of Exercise Sciences, Faculty of Kinesiology and Physical Education, at the University of Toronto. She has extensive experience as a competitive soccer athlete and coach, and her research interests include the study of women in coaching.

Gretchen Kerr is a full professor and the Vice-Dean of Academic Affairs in the Faculty of Kinesiology and Physical Education at the University of Toronto. As Vice-Dean, Professor Kerr is responsible for providing leadership and oversight of the development, management, co-ordination, accreditation, and evaluation of all undergraduate and graduate degree programs in the faculty. She has over 15 years of experience leading curriculum development and evaluation in the faculty, including the oversight of all experiential education opportunities, which encompasses internships, directed research, and practica. Professor Kerr also has an extensive publication record with respect to the safeguarding of young people in sport. 